Annales Missiologici Posnanienses t. 19 (2014), s. 7-36

DOI: $10.14746 / \mathrm{amp} .2014 .19 .1$

JERZY STRZELCZYK

Instytut Historii Uniwersytetu im. Adama Mickiewicza w Poznaniu

\title{
Rozmowa o historii misji średniowiecznych
}

Z prof. Jerzym Strzelczykiem, historykiem-mediewistą $\mathrm{z}$ Uniwersytetu im. Adama Mickiewicza w Poznaniu rozmawia o. dr hab. Paweł Zając OMI.

P.Z. - Panie Profesorze, czy nauka ma jeszcze coś nowego do powiedzenia na temat misji chrześcijańskich z okresu między późnym antykiem a końcem wczesnego średniowiecza? Czy są jeszcze jakieś niezbadane obszary, czy też musimy powtarzać ustalenia wcześniejszych pokoleń historyków?

J.S. - Nauka, także humanistyka, nigdy nie ma charakteru definitywnego, ciągle się rozwija. Nieustannie są wypracowywane nowe sposoby i nowe metody, nie mówiąc o tym, że każda epoka ma prawo i obowiązek spoglądania na przeszłość przez pryzmat własnych doświadczeń. Nie tylko historia ma być nauczycielką życia, ale wiemy też, że to życie jest nauczycielem historii. Oddziałuje przeróżnie na historyków, nie zawsze w sensie pozytywnym, na szczęście, jeżeli chodzi o historyków epok bardziej odległych, w stopniu mniejszym, niż jeżeli chodzi o historię niedawno minioną, tym bardziej żywą, palącą, aktualną. Historyk w czasach odległych jest jak gdyby bardziej swobodny. Nie ciąży mu aż takie ciśnienie aktualnych oczekiwań czy potrzeb. Jednak z tego ogólnego poziomu przejdźmy już do bardziej praktycznej strony. Mimo że badania nad misjami chrześcijańskimi w tym dawnym okresie mają długie tradycje i wiemy o nich dosyć dużo, to jeszcze daleko do wyjaśnienia wszystkiego, poza tym zmieniają się interpretacje. Często można odnieść wrażenie, że niektórych „białych plam” - luk w naszej wiedzy, po prostu nie da się wyeliminować. Przede wszystkim całe obszary historii wczesnego średniowiecza Europy wymykają się naukowemu rozpoznaniu. Żeby daleko nie szukać, odwołajmy się do przykładu Polski. Jeżeli chodzi np. o chrystianizację Polski, o misjach, które zapewne na terenie Polski działały, nie wiemy prak- 
tycznie nic. Podobnie jak nie wiemy nic o tym, co było przed tym na ziemiach polskich, tzn. o religiach wcześniejszych, pogańskich. Zresztą do kwestii religii pierwotnych jeszcze będę miał okazję, mam nadzieję, wrócić.

Nie wszystkie obszary mogą się tutaj poszczycić wystarczająco jasnym obrazem. Jest to, oczywiście, rezultat istnienia czy nieistnienia, bogactwa czy ubóstwa, a przede wszystkim jednostronności i fragmentaryczności podstawy źródłowej. Jak wiadomo, gdzie nie ma źródeł, tam nie ma historii. Na szczęście pojęcie źródła historycznego jest dynamiczne. Im bardziej badania historyczne się rozwijają, tym bardziej poszerza się pojęcie źródła historycznego. Dawniej pod pojęciem źródła historycznego miano na myśli tylko tzw. źródła pisane, i to właściwie nie wszystkie spośród nich. Historyków interesowała ta ich część, która była najłatwiej „,czytelna”, np. roczniki, kroniki, żywoty świętych. Natomiast bardzo wiele produktów piśmiennictwa, które my obecnie zaliczamy do źródeł, uchodziło uwadze, np. źródła liturgiczne, egzegetyczne czy homiletyczne. Wraz z rozwojem badań historycznych rozmaite kategorie, które wcześniej nie były dostrzegane albo przynajmniej doceniane, stają się takimi. Trzeba ponadto powiedzieć, że zmienia się również stosunek do źródeł. Dawniej źródło historyczne traktowano wyłącznie jak przekaz, żeby uciec się do takiego porównania: wybierano z niego poszczególne fakty i wydarzenia $i$ to one stanowiły przedmiot zainteresowania. Natomiast obecnie uważa się, że źródło należy traktować całościowo, integralnie. Warto więc interesować się nie tylko tym, co autor źródła chciał przekazać, czyli informacjami, ale również samym źródłem, które przecież powstało w określonym czasie i odzwierciedla daną epokę albo np. światopogląd autora. Przykładem tego mogą być źródła hagiograficzne, a szczególnie ich kategoria zwana mirakle. Są to utwory przedstawiające cudowne wydarzenia, które za sprawą jakiegoś świętego miały się dokonywać. Zdarzają się bardzo długie i niekiedy nużące utwory tego typu. Dawniej historiografowie, którzy byli zapatrzeni tylko na wspomnianą pierwszą stronę, czyli przekaz, uważali, że są to źródła, które w ogóle nie są przydatne dla historyka lub są dla niego w niewielkim stopniu interesujące. Któż byłby przecież gotów uwierzyć w prawdziwość tylu i takich cudownych wydarzeń? Te opowieści mogły być - uważano - interesujące ewentualnie dla etnografa, ale nie dla szukającego dziejowej prawdy historyka. Tymczasem takie mirakle mogą być bardzo cennym, niekiedy wręcz nieocenionym źródłem. Mam na myśli nie tyle kwestię subiektywnej prawdziwości opowieści o cudach, tego że dla autora i dla ówczesnych ludzi były one prawdziwe, lecz przede wszystkim tego, że odzwierciedlają światopogląd autora i tych, do których ten przekaz był skierowany. Dzięki źródłom hagiograficznym, także typu mirakle, historyk często zyskuje szansę wniknięcia w średniowieczny świat głębiej, niż byłoby to możliwe za pomocą powszechnie uznanych i tradycyjnie wykorzystywanych kategorii źródeł, takich jak roczniki i kroniki. 
Jeżeli chodzi o dzieje chrystianizacji i misji, źródła hagiograficzne często odgrywają dużą rolę. To właśnie hagiografia stanowi podstawowy zrąb materiału historycznego, na przykład w przypadku najwcześniejszego średniowiecza aż do czasów karolińskich w Galii. Bez tekstów hagiograficznych bardzo mało byśmy wiedzieli o tym, co się działo w Galii Merowingów, już nie tylko w sensie religijnym, ale w ogóle. Oczywiście ciągle ujawniają się nowe źródła, jednak w odniesieniu do wczesnego średniowiecza raczej nie można liczyć, że jeszcze nie zostały odkryte jakieś rewelacje, choć coś tam jeszcze niekiedy się znajduje. Jeszcze nie wszystkie archiwa zostały wystarczająco zbadane, czasami badacze natrafiają na jakieś wymazane czy wydrapane fragmenty pod późniejszymi tekstami (tzw. palimpsesty), już nie mówiąc o papirusach egipskich, palestyńskich czy syryjskich, które ciągle jeszcze się odkrywa, wreszcie o tekstach zapisanych na tabliczkach glinianych odnajdywanych, niekiedy w znacznych ilościach, zwłaszcza na obszarze starożytnej Mezopotamii.

W tej chwili podstawowym postulatem badań historycznych jest uwzględnianie w miarę możliwości innych kategorii źródeł poza pisanymi. Nazwijmy je - dla uproszczenia - materialnymi. Przede wszystkim mam na myśli źródła archeologiczne, które bardzo wiele potrafią pomóc historykowi wczesnego średniowiecza. Marny to byłby w dzisiejszych czasach historyk wczesnego średniowiecza, który chciałby się ograniczyć wyłącznie do źródeł pisanych. Często w ogóle nie miałby o co rąk zahaczyć. Archeologia znakomicie rozszerzyła i w głąb, i wszerz możliwości poznania historycznego. Źródła pisane na ogół dotyczą wyłącznie warstw uprzywilejowanych, tych które panowały, rządziły albo miały w tym czasie monopol piśmienności, czyli kręgów zbliżonych do dworu panującego, dworów biskupich lub do niektórych klasztorów. Właśnie źródła archeologiczne pozwalają przynajmniej do pewnego stopnia uchwycić życie ludzi prostych, zwykłych, którzy nie mieli żadnej szansy, żeby znaleźć się w tekstach pisanych. Archeologia jest obecnie nauką bardzo rozbudowaną, np. przez badania pozostałości architektonicznych z dawnych czasów znakomicie ułatwiła zdobywanie wiedzy czy poszerzyła jej krąg. Wspomnę o przykładzie ważnym dla misji. Ciekawym zjawiskiem są odkrywane w Skandynawii i nie tylko tam formy odlewnicze, z których można było odlewać z brązu zarówno chrześcijański krzyżyk, jak i tzw. młotek Tora, czyli znak pogański. Wydaje mi się, że jest to bardzo interesujące, dlatego że możemy uchwycić taki moment, kiedy to wpływy obydwu religii do pewnego stopnia jeszcze się równoważyły. Przedsiębiorczy rzemieślnicy potrafili przygotowywać takie sakralne drobiazgi zarówno na potrzeby pogan, jak i chrześcijan. Archeologia jest w tej chwili obudowana rozmaitymi innymi wspomagającymi dyscyplinami, jak antropologia, paleobotanika itd. To jeszcze nie wszystko, mógłbym dalej jeszcze wyliczać dziedziny, które powinny znajdować się w polu widzenia historyka wczesnego średniowiecza, ale to by za długo trwało. 
Oczywiście w miarę jak zasób źródeł pisanych się powiększa, rola archeologii się zmniejsza. Gdy historyk ma do dyspozycji dużo źródeł pisanych, może na ich podstawie próbować rekonstruować przeszłość. W Polsce badania historyczne mogą opierać się wyłącznie lub prawie wyłącznie na źródłach pisanych, dopiero gdy dotyczą okresu mniej więcej od połowy XIII w. Zasób tych źródeł sprzed połowy XIII w. jest stanowczo zbyt skąpy, żeby na ich podstawie można było pokusić się o zrozumienie i poznanie dziejów Polski. Na szczęście istnieją jeszcze inne sposoby poznawania przeszłości, np. metoda antropologiczna, polegająca na porównywaniu podobnie żyjących różnych ludów. O Polsce przed Mieszkiem I nie wiemy w zasadzie nic, a i w odniesieniu do późniejszych czasów, bezpośrednio po jego śmierci, nasza wiedza jest bardzo znikoma. Co ma robić historyk? Może uciekać się do porównań, szukać sytuacji porównywalnych, np. w ówczesnych Czechach, które były na zbliżonym stopniu rozwoju, albo np. w Saksonii, jednak uwaga: w Saksonii nie z X w., bo wtedy Saksonia była na znacznie wyższym stopniu rozwoju, ale w Saksonii czasów Karola Wielkiego (z przełomu wieku VIII-IX), kiedy według wszelkiego prawdopodobieństwa tamtejsze stosunki niewiele się różniły od Polski z X w. Sposobów przełamywania bariery źródłowej jest więcej, oczywiście trzeba z nich zawsze korzystać świadomie i ostrożnie, ale od tego jest historyk, żeby potrafił sobie z tym poradzić.

P.Z. - Jaki obraz misji chrześcijańskich we wczesnym średniowieczu wyłania się ze zgromadzonych dotąd i przeanalizowanych źródeł? Zdaję sobie sprawę, że to jest pytanie bardzo szerokie, ale chodziłoby o uchwycenie zasadniczych cech charakterystycznych. Pojęcie „obrazu” jest dość popularne w historiografii, chętnie pisze się o „obrazie” danych ludów w literaturze misyjnej i pismach misjonarzy. „Obraz” to jest często coś bardzo subiektywnego, ale właśnie chciałbym o taką perspektywę zapytać: jaki obraz misji wczesnochrześcijańskich wyłania się z badań i doświadczenia Pana Profesora?

J.S. - Przede wszystkim ogromnego poświęcenia ze strony misjonarzy, wielkiej gorliwości, zwłaszcza jeżeli chodzi o ten najwcześniejszy czas, powiedzmy - czasy apostolskie czy postapostolskie. Rozpowszechnione było przekonanie, że zbliża się paruzja, że nie przeminie to pokolenie, a nastąpi ponowne przyjście Chrystusa i kres tego świata. Motyw ten we wczesnym średniowieczu, ale i około roku 1000, odgrywał sporą rolę. Oczekiwano, że taka „okrągła" milenijna data zwiastuje koniec świata, więc w takich sytuacjach, podobnie jak w okresie początkowym, nastawienie chrześcijan było takie, że należy dążyć do tego, by jak największą liczbę dusz pozyskać dla prawdziwej wiary. Wiadomo, że panowała doktryna wyłączności zbawienia w obrębie Kościoła. Poza Kościołem - jak wierzono - zbawienia nie ma. Ludzie byli o tym święcie 
przekonani, a zatem dzieło misyjne było motywowane miłosierdziem. Chodziło o to, żeby jak najwięcej dusz oderwać od fałszywej wiary. Stąd pewnie ta niesamowita żarliwość. $Z$ drugiej strony trzeba powiedzieć, że w okresie wcześniejszego średniowiecza (mam tu na myśli okres do przełomu I i II tysiąclecia) dzieło misyjne bynajmniej nie rozwijało się prostolinijnie, przeciwnie - można zaobserwować wyraźne fazy przyspieszenia, ale także jak gdyby zastoju. Pierwszy okres takiej niewątpliwej intensyfikacji to wspomniany przeze mnie okres apostolski i postapostolski, kiedy religia chrześcijańska, początkowo religia niewielkiej grupy biedaków na Ziemi Świętej, stawała się religią dominującą na obszarze ogromnego cesarstwa rzymskiego. Mimo Dziejów Apostolskich i innych źródeł właściwie niewiele o tej fazie wiemy. Pamięć historyczną przytłacza tutaj postać św. Pawła, jego niewątpliwie epokowy udział w dziele misyjnym. Jednak o terenach, do których nie dotarł św. Paweł, wiemy bardzo mało. Przykład: nie wiemy nic o początkach chrześcijaństwa na terenie samego Rzymu. Wiadomo, że apostoł Paweł spotkał tam chrześcijan, ale skąd się ci chrześcijanie wzięli, nie wiadomo. Nic nie wiadomo o najwcześniejszym chrześcijaństwie w Egipcie, czyli na jednym z najważniejszych pod względem ekonomicznym, ale także duchowym, obszarów imperium rzymskiego. Po prostu Paweł tam nie ewangelizował i nie wiemy, kto tego dzieła dokonał. Uogólniając, trzeba podkreślić, że nasza wiedza jest niewielka, fragmentaryczna, ale nie zmienia to postaci rzeczy, że w ciągu trzech pierwszych stuleci misji chrześcijańskiej dokonała się w dużym stopniu chrystianizacja największego i najtrwalszego dotąd w dziejach ludzkości imperium, jakim było imperium rzymskie.

Wiek IV przyniósł zasadniczą zmianę. Cesarstwo rzymskie stało się cesarstwem chrześcijańskim w ciągu IV stulecia od Konstantyna do Teodozjusza Wielkiego. Sytuacja chrześcijan diametralnie się zmieniła, mówiąc obrazowo - mogli wyjść z katakumb. Pod koniec IV w. chrześcijaństwo stało się jedyną religią oficjalnie wyznawaną $\mathrm{i}$ - co tu dużo mówić - chrześcijanie zaczęli prześladować tych, którzy inaczej wierzyli. Pojawiły się także w obrębie chrześcijaństwa różne kierunki i nurty, które teolog nazywa heretyckimi, ale o których historyk może powiedzieć tylko (czy: aż) tyle, że były, jak np. arianizm czy donatyzm w Afryce, pewną alternatywą dla rzymskiej religii. Właściwie przez kilka stuleci chrześcijaństwo na Zachodzie ograniczyło się do obszarów cesarstwa. Wprawdzie pod koniec V w. cesarstwo przestało istnieć na Zachodzie, ale nadal istniało poczucie pewnej jedności cywilizacyjnej. Nie mówię w tej chwili w zasadzie o cesarstwie wschodnim, muszę się skoncentrować na tym, co nam bliższe. Nie widać w tym okresie ani chęci, ani zapewne możliwości wyjścia chrześcijaństwa poza obszar istniejącego (albo - od końca V w. - już faktycznie nieistniejącego) cesarstwa na Zachodzie. Rozumiemy, że rozciągało się tam bardzo szerokie pole misji wewnętrznej i trzeba było te ogromne 
obszary nie tylko formalnie, ale i faktycznie schrystianizować. W ówczesnych warunkach, kiedy nie było radia, telewizji, internetu, telefonu ani prasy, trzeba było osobiście docierać do ludzi. Mimo doskonałych dróg rzymskich poza nimi bardzo trudno było się poruszać. Musiały minąć wieki, zanim nowa chrześcijańska religia mogła trafić „pod strzechy”, nie mówiąc już o tym, że środowiska wiejskie, wieśniacze, zawsze i wszędzie są nastawione bardziej konserwatywnie i są oporne wobec wszelkich nowości. Rolnicy byli głębiej niż mieszkańcy miast przywiązani do tradycyjnych kultów, które były wplecione w ich życie. W miastach, zwłaszcza miastach portowych, zawsze prędzej upowszechniały się wszelkie nowinki, także nowe religie. Chrześcijaństwo w tym początkowym okresie było religią przede wszystkim miast, tak że wiele czasu minęło, zanim chrześcijaństwo rzeczywiście objęło przynajmniej formalnie zdecydowaną większość mieszkańców imperium. Zresztą mogli być formalnie chrześcijanami, ale co tak naprawdę w głębi duszy czuli, trudno powiedzieć. O tym, że wieś była bardzo oporna, świadczy argument językowy, słowo ,paganus”, czyli wieśniak, stało się synonimem poganina, niechrześcijanina. To mogło się zmieniać jedynie stopniowo.

Ponowna, druga faza intensywnej chrystianizacji, która wreszcie śmiało wykroczyła poza granice dawnego imperium rzymskiego, rozpoczęła się na przełomie wieku VI i VII. Zainaugurował ją pontyfikat papieża Grzegorza I Wielkiego misją wśród pogańskich Anglosasów, którzy w międzyczasie opanowali dużą część większej z Wysp Brytyjskich. Ten drugi etap objął przede wszystkim chrystianizację Brytanii rzymskiej, a w następnym etapie - Germanii. Później nastąpiło coś w rodzaju ochłodzenia aktywności misyjnej. Wiadomo, że np. biskupi w Saksonii, która została schrystianizowana i przyłączona do imperium Karola Wielkiego, nie wykazywali szczególnej gorliwości misyjnej. Podobnie Grzegorz Wielki wcześniej miał kłopoty z biskupami z Galii, którzy wcale nie byli skłonni do współpracy przy ewangelizacji Anglosasów. Analogicznie było, jak się wydaje, jeszcze później w Polsce. Podobno Bolesław Krzywousty nie mógł znaleźć w episkopacie polskim pomocy przy chrystianizacji Pomorzan, musiał więc szukać misjonarzy poza Polską. To są ciągle podobne sytuacje. Episkopat miejscowy miał dosyć problemów we własnym kraju i wcale mu nie było pilno do wychodzenia poza te obszary. Można to zresztą zrozumieć.

Trzecia faza rozpoczęła się gdzieś w IX w., a w stuleciu X i na początku XI objęła ogromne obszary Europy Środkowo-Wschodniej, tj. obszar Czech, Polski, Węgier, Skandynawii i Rusi, która zajmowała ogromne terytorium, z tym że jeżeli chodzi o Ruś, a także Bułgarię, to nie Rzym, lecz Konstantynopol odegrał wiodącą rolę. Kraje te stały się krajami Kościoła wschodniego, prawosławnego. W tym momencie można powiedzieć, że około 1000 r. Europa w zasadzie była już kontynentem chrześcijańskim. W zasadzie, bo jeszcze 
niezupełnie. Co było jeszcze niechrześcijańskiego w Europie około 1000 r.? Przede wszystkim całe wschodnie i południowe pobrzeże Bałtyku, poczynając od Zatoki Fińskiej, czyli ludy zachodniofińskie, np. Estowie, bałtyjskie - Łotysze, Litwini, Prusowie i słowiańskie - Pomorzanie i północni Połabianie. Był to tzw. nadbałtycki klin albo enklawa pogańska z wierzchołkiem w okolicach Hamburga. Ten klin pogański był dopiero stopniowo likwidowany. Pierwszego wyłomu dotyczącego Pomorza dokonał Bolesław Krzywousty we współpracy z Ottonem z Bambergu. Potem przyszła kolej na Połabian północnych, to jest jeszcze XII w., następnie w XIII i XIV stuleciu ludy wschodniego pobrzeża Bałtyku. Ostatnim pogańskim obszarem Europy, jak dobrze wiadomo z historii Polski, była Litwa i Żmudź, które dopiero na końcu wieku XIV lub w przypadku Żmudzi na początku XV stulecia oficjalnie przyjęły chrześcijaństwo. Oprócz tego trzeba powiedzieć, że około 1000 r. jedność konfesyjną Europy chrześcijańskiej mąciła jedynie Hiszpania czy raczej Półwysep Pirenejski; Hiszpania, w której już od dłuższego czasu trwała rekonkwista (proces odwojowywania kraju z rąk muzułmanów), niemniej jednak około 1000 r. nadal islam był tam dominujący. Ten stan będzie się zmieniał stopniowo dopiero w następnych wiekach. Jak wiadomo, dopiero pod koniec stulecia XV muzułmanie zostaną ostatecznie wyparci z Hiszpanii. W drugiej połowie XIV w. na innym krańcu Europy pojawią się Turcy Osmańscy, zawojują duże części Bałkan, będą atakowali Węgry i Austrię. W połowie XV w. położą kres cesarstwu wschodniemu. Była to zatem nowa fala ekspansji muzułmańskiej na obszar Europy, która jednak już nie dotarła bardziej na zachód. Nie można wreszcie zapominać o diasporze żydowskiej, która cały czas istniała w Europie. Jak się wydaje, poza Hiszpanią wizygocką nie podlegała jakimś specjalnym restrykcjom. Gminy żydowskie miały się na ogół zupełnie nieźle, często znajdowały się pod specjalną ochroną panujących, co nawet u niektórych zelotów chrześcijańskich powodowało odruchy niechęci, zniecierpliwienia, a nawet otwartej wrogości.

Jeżeli chodzi o pewne cechy działalności misyjnej wcześniejszego średniowiecza, myślę że jeszcze będę miał okazję przy następnych pytaniach zwrócić uwagę na rozmaite sytuacje, z jakimi misjonarze spotykali się w Europie. W tej chwili chciałbym tylko wspomnieć model chrześcijaństwa w Irlandii. Było to bardzo ciekawe zjawisko, wyjątkowe także w sensie chronologicznym. Wspomniałem, że dopiero pontyfikat Grzegorza I Wielkiego przyniósł wyjście misji chrześcijańskich poza obszar zachodniego cesarstwa rzymskiego. Irlandia była wyjątkiem, jedynym jeśli chodzi o chrześcijaństwo zachodnie, bowiem chrystianizacja Irlandii dokonała się w dość tajemniczych okolicznościach, ale jeszcze $\mathrm{w}$ okresie istnienia cesarstwa rzymskiego, tzn. w ciągu V stulecia. Analogię wschodnią stanowiłyby takie tereny, jak Etiopia i Armenia, które również w okresie wcześniejszym, jeszcze kiedy istniało cesarstwo rzymskie, stały się w dużym stopniu krajami chrześcijańskimi. Armenia do 
dziś dnia chlubi się tym, że była pierwszym królestwem oficjalnie chrześcijańskim. Nie omawiam, czyli zostawiam na marginesie mimo doniosłości zjawiska, ogromne, pod względem zasięgu i dynamiki właściwie z niczym nieporównywalne w tym czasie, misje Kościołów nieortodoksyjnych na wschodzie, Kościoła jakobickiego, a zwłaszcza nestoriańskiego, których wyznawcy po Soborze Chalcedońskim uznani za heretyków, byli prześladowani na obszarze cesarstwa bizantyńskiego. Uszli na wschód, prowadząc niezwykle interesującą i ciągle mało znaną działalność misyjną, która doprowadziła ich w różnych okresach aż na Daleki Wschód, na obszar Mongolii i Chin. Jest to bardzo ciekawa karta w dziejach misji chrześcijańskich. Obecnie staramy się spoglądać na chrześcijaństwo w możliwie szerokim aspekcie, uwzględniając również te nurty i odłamy, które wyłamały się z obediencji rzymskiej czy konstantynopolitańskiej. Dlatego im również musimy oddać zasługi, o których przed chwilą wspominałem. Mogę powiedzieć tyle, że ze ściśle geograficznego, terytorialnego punktu widzenia zasięg misji nestoriańskich był znacznie większy niż obszar Kościołów zachodnich, rzymskiego i konstantynopolitańskiego, razem licząc. Może na razie tyle, jeżeli chodzi o ten ważny problem.

P.Z. - Jak należałoby się odnieść do stereotypu chrystianizacji pogan „ogniem i mieczem"?

J.S. - Z punktu widzenia nauki Kościoła były one złem i wypaczeniem idei. Przyjęcie chrześcijaństwa powinno być aktem dobrowolnym, inaczej nie może mieć znaczenia. Jednak dziejowa konieczność była niestety czasem odmienna. Mogę tylko powiedzieć, że taki sposób krzewienia chrześcijaństwa, który za Sienkiewiczem określilibyśmy literacko jako „ogniem i mieczem”, a który ktoś ze współczesnych Karolowi Wielkiemu w odniesieniu do jego krwawego nawracania Sasów opisał, stwierdzając, że Karol Wielki nawracał Sasów „,żelaznym językiem", nie był, niestety, czymś zupełnie wyjątkowym w średniowieczu. Krytykując tego rodzaju użycie przemocy, należy jednak pamiętać, że, pomijając pewne fragmenty działalności misyjnej wśród Sasów, Słowian nadbałtyckich czy Bałtów (mam na myśli Prusów i Litwinów), na ogół doktryna kościelna odrzucała przymusową konwersję, a w samej działalności misyjnej starała się rozróżniać dwa etapy.

Pierwszy etap to depaganizacja. Po to żeby stworzyć warunki do swobodnego przyjmowania nowej wiary, trzeba było najpierw zabronić wyznawania dawnych kultów przedchrześcijańskich, wykorzenić je, zniszczyć idole, ewentualne świątynie, święte gaje. Święty Bonifacy dlatego ścinał święty dąb, poświęcony Torowi, by dać widzialny znak, że te bóstwa już nie istnieją bądź są bezsilne. Depaganizację, jeżeli nie dało się inaczej, można było, a nawet należało, przeprowadzić siłą, ale to nie była jeszcze chrystianizacja. 
Potem powinien nastąpić drugi etap - confessio fidei, czyli przyjęcie wiary chrześcijańskiej. Powinno to mieć charakter dobrowolny, tzn. powinno się przekonywać tych jeszcze niedawnych pogan do uznania wyższości wiary chrześcijańskiej. Nie zawsze dawało się zapobiec temu, że w praktyce pomiędzy depaganizacją a przyjęciem nowej wiary występował okres przejściowy, kiedy nie wolno było już czcić dawnych bogów, a jeszcze nie poznano prawdziwej wiary. To oczywiście prowadziło do zjawiska dwuwiary, tj. wierzyło się i w jedno, i w drugie. Jednak to były chyba nieuchronne skutki. Trzeba przede wszystkim pamiętać, że umysły ludzi, Germanów, Celtów, Słowian, były często dość oporne wobec nowej wiary. Przyjęcie wiary chrześcijańskiej to nie była zwykła zamiana jednej religii na drugą. Sytuacja była odmienna niż np. na obszarze cesarstwa rzymskiego. Tutaj sytuacja była znacznie bardziej skomplikowana, to nie była tylko nowa religia, to był w ogóle rewolucyjnie nowy światopogląd, nowy sposób spoglądania na świat. Dlaczego? Dlatego, że religie prymarne (pogańskie) miały zupełnie inny charakter, inny cel. Celem tej religii była pomyślność społeczności, rodu, plemienia, narodu. Ona nie była skierowana ku jednostce, tylko ku społeczności, była skierowana na doczesność, miała zapewnić tej społeczności szczęście, pomyślność, dostatki, urodzaje, przewagi wojenne w tym życiu. Sfera pozaziemska była bardzo słabo rozwinięta. Na ogół zdawano sobie sprawę, że śmierć nie oznacza końca bytu ludzkiego, ale tę przestrzeń wyobrażano sobie bardzo niejasno. Taka była perspektywa, chrześcijaństwo ją zupełnie zmieniało. Celem religii chrześcijańskiej nie jest zapewnienie człowiekowi czy społeczności pomyślności w życiu doczesnym, choć oczywiście tego także oczekiwano i wierzono, że przyjęcie chrześcijaństwa przyniesie korzyści również doczesne. Chrześcijaństwo prowadzi ludzi do zbawienia, kładzie akcent na życie przyszłe. Spróbujmy sobie wyobrazić, jakie to trudne było do pojęcia przez ówczesnych ludzi, którzy o życiu pozagrobowym mieli dość mierne wyobrażenie.

Religie poprzedzające chrześcijaństwo miały charakter politeistyczny. Było wielobóstwo, nawet jeżeli jedno z tych bóstw wybijało się na pierwsze miejsce wśród innych, jak np. słowiański Swarożyc, prawdopodobnie u Słowian zachodnich, czy Perun wśród Słowian wschodnich, albo Odyn wśród mieszkańców Północy. Wielobóstwo miało charakter partykularny, każda społeczność, powiedzmy - każde plemię, miało swój panteon. Społeczność czuła się związana ze swoim bóstwem, składano mu ofiary, niekiedy krwawe, ale oczekiwano jego przychylności. Jeżeli tej przychylności nie było, bo np. nieurodzaje trapiły albo dane plemię czy lud ponosił ciągle klęski, to mogło świadczyć o tym, że bóstwa albo odwróciły się od nich, albo są bezsilne. Widocznie bóstwo, któremu ten zwycięski sąsiad oddaje cześć, jest ważniejsze, lepsze, a zatem warto by czcić to bóstwo. Żeby całkowicie nie zarzucić tradycyjnego kultu, to może warto przyjąć również tamtego boga do swego pante- 
onu. Poganie nie mieli z tym żadnego problemu. Ich panteon był elastyczny. Wyobrażano sobie podobnie, że będzie tak z nową religią. Przy tym trzeba dodać, że właściwie dla pogan jedyną postacią z całej Trójcy Świętej, z którą wiedzieli, co począć, była druga osoba, czyli Chrystus. Pojęcie Boga Ojca było czymś tak odległym, że właściwie mało istotnym, a już postać Ducha Świętego w ogóle nie była do pojęcia. Tak że właściwie Chrystus był jedyną postacią, z którą można było się identyfikować, którą można było rozumieć. Jeżeli ci chrześcijanie są tacy natarczywi, a co więcej - jeżeli mają przewagę (a tak najczęściej było, bo chrześcijaństwo było na ogół religią państw wyżej rozwiniętych), to przyjmijmy Chrystusa do swojego panteonu. Postawmy mu obok posągu Odyna czy Swarożyca, może nawet na bardziej honorowym miejscu, jego posąg. Chętnie będziemy go czcić. Nie mogli tylko zrozumieć, dlaczego chrześcijanie nie godzą się na to. Oczywiście chrześcijanie nie mogli na to pozwolić ze względu na monoteistyczny charakter swojej religii. Takich punktów niezgody i niezrozumienia było więcej. Musiało trochę potrwać, zanim wiara chrześcijańska została rzeczywiście wszczepiona tym ludziom.

P.Z. - Czy były jakieś etapy przejścia od chrześcijaństwa pojmowanego w kategoriach siły politycznej do poznania jego prawdziwej siły duchowej?

J.S - Na pewno to był proces dość długotrwały. Wydaje mi się, że warunkiem koniecznym była rozbudowa struktury kościelnej. Zanim dany obszar niedawno schrystianizowany został pokryty siecią klasztorów, które we wczesnym średniowieczu odgrywały szczególnie doniosłą rolę, ale także siecią parafialną, ponieważ jedynie sieć parafialna mogła zapewnić bezpośredni kontakt duchownych z wiernymi, musiał upłynąć dość długi czas. Religia chrześcijańska długo miała raczej charakter deklaratywny. Ludzie prości nie za bardzo wiedzieli, jakie są prawdziwe zasady wiary chrześcijańskiej.

Na ziemiach polskich taka zorganizowana sieć duszpasterska powstała dopiero w XIII-XIV w. Przedtem były tylko nieliczne klasztory i dwory biskupie. Stąd siła oddziaływania była ograniczona. Im dalej od tych klasztorów i siedzib biskupich, tym chrześcijaństwa, mówiąc obrazowo, było mniej. Nie ulega wątpliwości, że daleko w jakichś puszczach, może nawet nie otwarcie deklarowane, ale faktyczne pogaństwo zachowało się jeszcze daleko w głąb średniowiecza. Chrystianizacja to długotrwały proces. Jest takie stanowisko teologiczne, chyba nie całkowicie pozbawione racji, że proces chrystianizacji w sensie uwewnętrznienia nauki chrześcijańskiej ma charakter ciągły i właściwie nigdy nie zostanie zakończony. Przy naszych ludzkich słabościach także tak bym to widział. 
P.Z. - Czy przetrwanie mitologii pogańskiej jest spowodowane nieskuteczną depaganizacją, czy może w ogóle nie było mitologii pogańskiej, jak niektórzy twierdzą, np. w przypadku Słowian? Jakie jest osobiste zdanie Pana Profesora?

J.S. - Wydaje się, że tak rozwiniętych systemów mitologicznych jak u Celtów i Germanów skandynawskich w kontynentalnej Germanii raczej nie było, tym bardziej u Słowian. To wszystko, co na temat mitologii słowiańskiej wymyślił w XV w. Jan Długosz czy tym bardziej późniejsi autorzy, można między bajki włożyć. Pewnie więc rzeczywiście pod tym względem Słowiańszczyzna nie przodowała. Dlatego raczej nie ma specjalnie filmów opartych na kanwie mitologii słowiańskiej, w przeciwieństwie do ciągle oglądanych w telewizji filmów dotyczących mitologii wikingów czy Celtów.

P.Z. - Zdaje mi się że prof. Maria Janion w książce Niesamowita Słowiańszczyzna sugerowała, zgodnie z niektórymi autorami wcześniejszymi, zafascynowanymi słowiańskością, że musiało tutaj zaistnieć jakieś celowe i agresywne niszczenie pamięci pogańskiej.

J.S. - Tak, z tym bym się do pewnego stopnia zgodził. Na ziemiach polskich, ale nie tylko w Polsce, bo też w Czechach, praktycznie nie mamy wiadomości nie tylko o mitologii, ale wręcz o religii pogańskiej. Pamięć się nie zachowała, w przeciwieństwie np. do Pomorzan czy Połabian z jednej strony, do Rusi $\mathrm{z}$ drugiej strony, tak że całą naszą w dużym stopniu hipotetyczną wiedzę o słowiańskim pogaństwie czerpiemy właśnie ze źródeł dotyczących Pomorzan czy Połabian i Rusi Kijowskiej. To chyba dowodzi skuteczności depaganizacji. Niestety, nie wiemy o tym nic konkretnego, ale ponieważ przyjęcie chrześcijaństwa łączyło się z krzepnięciem władzy państwowej, to można założyć, że Mieszko I i jego następcy, ręka w rękę z biskupami i misjonarzami, bardzo gruntownie starali się wyrugować z pamięci wszystko to, co mogło dotyczyć pogaństwa. Ktoś kiedyś przyrównał wczesne państwo, które chrześcijaństwo wprowadzało, do ogromnego potwornego walca, który się przetaczał przez te ziemie, wyrównując wszystko. Było to dobre z punktu widzenia państwa, ponieważ partykularyzmy miejscowe związane $\mathrm{z}$ religią pogańską były niwelowane. Czy to dobrze dla kultury, trudno powiedzieć. Ale tak właśnie było. Proszę zwrócić uwagę, że nasz najstarszy kronikarz, wprawdzie obcego pochodzenia, ale reprezentujący dworską tradycję, tzw. Gall Anonim, nie miał nic do powiedzenia na temat pogaństwa. Czy rzeczywiście już na dworze Bolesława Krzywoustego o wszystkim zapomniano? W dużym stopniu pewnie tak, ale przede wszystkim nie chciano zapewne do tego wracać. Dopóki jeszcze gdzieś tam tliły się pozostałości pogaństwa, a przecież w latach trzydziestych i czter- 
dziestych XI w. nastąpiła groźna reakcja pogańska w Polsce, dopóty gdzieś tam jeszcze jacyś ukryci w lasach kapłani pogańscy zapewne istnieli i czekali na stosowną chwilę, by wyjść z podziemia. Uważam, że państwo wczesnopiastowskie i Kościół w tym państwie w dużym stopniu przyczynili się do tego że ślady pogaństwa zostały dość skutecznie wyrugowane także z pamięci historycznej Polaków.

P.Z. - Panie Profesorze, wymienię tutaj tylko kilka Pana publikacji: Goci rzeczywistość i legenda, Iroszkoci w kulturze średniowiecznej Europy, Wandalowie $i$ ich afrykańskie państwo. Może nietypowe pytanie: Gdyby podróż w czasie była możliwa, któremu z tych ludów chciałby Pan Profesor jeszcze bliżej się przyjrzeć?

J.S. - Już tak jest, że tematu, który kiedyś mnie fascynował, staram się nigdy nie tracić z pola widzenia. Mimo że już nie napiszę nowej książki o Gotach, o Iroszkotach, o Wandalach czy o Longobardach (książka o Longobardach ukazała się kilka miesięcy temu), to staram się być na bieżąco, oczywiście w miarę możności, z tym, co nauka na ten temat ma do powiedzenia. Gdybym miał do tej tematyki wrócić, to chyba do iryjskiej (iroszkockiej), dlatego że tamte pozostałe są jakoś zamknięte. Oczywiście, nie w tym sensie, że już wszystko wiemy, ale że raczej, mimo całego postępu badań, nie możemy się spodziewać jakichś specjalnie wielkich odkryć w stosunku do dziejów Gotów czy Wandalów. Jeżeli chodzi zaś o Iryjczyków i ich rolę w europejskiej cywilizacji, ciągle jeszcze sporo zostało do zrobienia. $Z$ punktu widzenia polskiego uczonego, który nie włada językiem gaelickim, występuje trudność dotarcia do wielu tekstów, np. do prawodawstwa iryjskiego, które było publikowane jedynie w języku oryginału, więc nie ma jak tego „ugryźć”. Poza tym, no cóż, coraz młodszy człowiek nie jest. Wprawdzie mam jeszcze pewne zamierzenia, ale w postaci jakiejś monografii do żadnego z tych trzech, łącznie z Longobardami czterech przypadków, raczej nie przewiduję wrócić, niech to robią inni, młodsi.

P.Z. - Trochę przewidywałem, że padnie odpowiedź: Iroszkoci, i przygotowałem co do nich dalsze pytania. Powszechnie przyjmuje się, że - tak jak Pan Profesor mówi - Iroszkoci wnieśli ogromny wkład w kształtowanie chrześcijańskiej kultury europejskiej...

J.S. - Chociaż czasem przeceniany...

P.Z. - Jednak też wciąż inspirujący dalsze badania. Co do Iroszkotów więc czy zgodnie z idealnym wyobrażeniem, które można nieraz zaczerpnąć wprost ze źródeł, była to rzeczywiście społeczność uczonych i świętych? 
J.S. - Nie, na pewno nie. To taki bardzo powierzchowny stereotyp. Faktem jest, że Irlandia, która nie zaznała ani rzymskiego panowania, ani wędrówek ludów, mogła trwać w swoim kształcie w sposób niezakłócony aż do najazdów wikingów, które rozpoczęły się pod koniec VIII w. Wyspa zatem długo nie zaznała żadnej inwazji zewnętrznej. W okresie wędrówek ludów rzeczywiście na tej wyspie chronili się zagrożeni intelektualiści, uczeni z kontynentu albo z Brytanii. Życie monastyczne tam się rozwijało, a klasztory rzeczywiście w pewien sposób gwarantowały przetrwanie czy rozwijanie kultury i piśmienności. Niemniej jednak stereotyp wyspy uczonych wydaje się przesadny, dlatego że wiemy obecnie, że poziom kultury piśmiennej, intelektualnej, także artystycznej w samej Irlandii był godny uwagi, ale mimo wszystko ograniczony. Był dość wysoki w porównaniu do ówczesnej sytuacji na kontynencie, ale raczej o charakterze elementarnym. Uczono tam podstaw łaciny, studiowano gramatykę, pisywano komentarze do Pisma Świętego, ale wybitne osiągnięcia kulturalne, intelektualne były raczej dokonywane przez Iryjczyków na kontynencie. Tam doszło do zetknięcia się Iryjczyków z rozwijającą się za czasów karolińskich kulturą kontynentalną i tam właśnie żyli najwięksi twórcy. Nie chciałbym tutaj minimalizować osiągnięć, ale wydaje mi się, że ten stereotyp, Irlandia - wyspą uczonych, jest troszkę przesadny, aczkolwiek faktem jest, że tak postrzegano niekiedy tę sprawę już $\mathrm{W}$ średniowieczu. W perspektywie średniowiecznej Europy Irlandia uchodziła za ostoję uczoności i faktycznie wiemy, że rozmaici adepci z Brytanii czy z kontynentu studiowali i uczyli się w tych klasztorach iryjskich, a potem wracali na kontynent, przenosząc i rozwijając tę wiedzę.

A świętych? Tutaj też ogromny problem... miałem okazję mówić o tym w czasie naszego wrześniowego sympozjum ${ }^{1}$. To jest pewien paradoks, bo rzeczywiście, gdy czytamy traktaty chrześcijańskie, które powstały w Irlandii lub w iryjskich kręgach poza nią, odnosi się wrażenie niezwykłej religijności i pogłębionej duchowości w stopniu takim, jaki na kontynencie trudno byłoby znaleźć. Jednak wiele wskazuje na to, że to jest powierzchowny obraz, że w rzeczywistości chrześcijaństwo w Irlandii, które zostało, o ile wiemy, zaszczepione w sposób pokojowy, a przynajmniej nie wiemy nic o jakichś znaczących konfliktach, nie tak bardzo zmieniło Iryjczyków. Nie znamy żadnych męczenników iryjskich sprzed inwazji wikińskiej. Chrześcijaństwo w sposób gładki i bezkonfliktowy bardzo silnie wkomponowało się w struktury społeczne Irlandii. Społeczeństwo iryjskie zaś miało bardzo tradycyjny charakter, właściwie tam się nawet nie wytworzyły większe plemiona. Ustrój społeczny został jak gdyby spetryfikowany na szczeblu związków rodowych, które czasem przez szkocką analogię nazywamy klanowymi. Nie było tam

1 Por. sprawozdanie ze wspomnianego sympozjum w niniejszym numerze „Annales”, przyp. PZ. 
miast w sensie antycznym, chrześcijaństwo przybrało formy nieznane w modelu Kościoła rzymskiego, mianowicie o charakterze monastycznym. Może nie $\mathrm{w}$ tym najwcześniejszym, ale $\mathrm{w}$ nieco późniejszym okresie stało się nieodłączną częścią tego społeczeństwa. Klasztory były jak gdyby własnością poszczególnych narodów. Wiele z nich przez całe stulecia było rządzonych przez opatów wywodzących się z jednej rodziny. Oczywiście powodowało to rozmaite konsekwencje, niekoniecznie pozytywne z punktu widzenia wiary chrześcijańskiej, np. wikłanie klasztorów w spory polityczne, walki, wojny wewnętrzne, których w Irlandii nigdy nie brakowało. Geograficzne i polityczne (wynikające z opanowania Brytanii przez Anglosasów) oddalenie od Rzymu i pewien dystans wobec papiestwa powodowały, że chrześcijaństwo iryjskie nabierało cech szczególnych. Najważniejszą był wspomniany, nie episkopalny, ale monastyczny model, gdzie indziej niewystępujący. Były też różnice mniej może ważne w naszym odczuciu, ale istotne dla ówczesnych ludzi, jak odmienny sposób obliczania daty Wielkanocy, całego roku kościelnego, a także bardzo zewnętrzny, ale symboliczny inny kształt tonsury kapłańskiej. Na terenie Brytanii model Kościoła iryjskiego, który od północy był transplantowany do Brytanii, zderzył się z Kościołem rzymskim, który Grzegorz Wielki tam zapoczątkował, i to zderzenie przybierało niekiedy drastyczne formy. Doszło do tego, że chrześcijanie rzymscy cieszyli się, kiedy jeden z królów iryjskich, który opowiedział się wcześniej za tą kolumbańską odmianą chrześcijaństwa, poniósł klęskę w bitwie z pogańskim królem anglosaskim. Zresztą obie strony nie przebierały w środkach, żeby tę drugą pognębić. Wydaje mi się, choć nie jest to pogląd powszechnie przyjęty, że Irlandia wczesnośredniowieczna, mimo pozorów chrześcijańskich, w gruncie rzeczy zachowała dużo cech pierwotnych. To społeczeństwo miało charakter przede wszystkim świecki, co wielu głębiej myślących chrześcijan nawet skłaniało do reakcji. Skoro nie znajdowali możliwości rozwoju własnej duchowości na miejscu, to udawali się gdzie indziej szukać ukojenia i spokoju oraz możliwości całkowitego oddania się sprawom duchowym. Zresztą to pozostaje właściwie ciągle do zbadania. W gruncie rzeczy niewiele bowiem wiemy, jaki był stopień chrystianizacji w społeczeństwie Irlandii we wczesnym okresie.

P.Z. - Czy w obliczu tego stereotypu, który właśnie poddajemy krytyce, tj. „Irlandii - wyspy świętych”, nie byłaby rzeczywiście szokująca surowość reguły Kolumbana. Skąd się brała taka surowość przepisów w dużym stopniu opartych na karach cielesnych?

J.S. - Mielibyśmy tu chyba dowód na to, że reguły klasztorne stanowią niezupełnie doskonałe odbicie społeczeństwa. Oczywiście nie mogą funkcjonować w próżni, wiele wskazuje na to, że ta surowość była reakcją na niski stopień 
chrystianizacji społeczeństwa. To było dzikie, surowe społeczeństwo, więc ci adepci, którzy do klasztorów przychodzili, nie zawsze z własnego wyboru, prawdopodobnie musieli być „krótko trzymani”. Jednak występuje też niewątpliwie dysproporcja pomiędzy surowością reguł, zwłaszcza kolumbańską, ale nie tylko nią, a tym, co skądinąd wiemy o chrześcijaństwie iryjskim. To chrześcijaństwo iryjskie w większym stopniu niż ówcześnie na kontynencie rozwinęło pewne cechy bardzo ujmujące i nietypowe dla epoki. Na przykład był taki święty, który działał na terenie dzisiejszej Szkocji, jeździł po wrzosowiskach, od wsi do wsi, na osiołku, nie na koniu, albo wręcz wędrował pieszo, głosząc wszędzie Ewangelię, nie uciekając się do żadnej pomocy ze strony świeckich. Były to czasy surowe, ale właśnie tylko w Irlandii we wczesnym średniowieczu widzimy specjalnie miły stosunek ludzi do zwierząt. Święty Kolumba Starszy na wyspie Iona, czując zbliżającą się śmierć, starał się obejść założony przez siebie klasztor i zobaczyć, czy wszystko jest w porządku. Jest taka zachowana scena, kiedy czule żegna się ze swoim rumakiem, wiernym koniem, który służył mu przez wiele lat. Gdzie indziej w Europie czegoś takiego nie znajdujemy. W żywotach Kolumbana Młodszego mamy epizody, w których święty nakazuje niedźwiedziowi, żeby nie jadł tego, co nie jest dla niego przeznaczone. Te fragmenty przekazują - z naszego punktu widzenia - naiwne rysy bliskości człowieka do zwierząt czy też obustronnej sympatii, bo te zwierzęta rzekomo słuchały świętego. Poza tym pouczająca jest lektura najstarszego żywota św. Brygidy. Wiadomo - Brygida to obok Patryka główna patronka chrześcijaństwa iryjskiego. Święta jeździ na wozie po południowej Irlandii. Ktoś przyrównał ją do wróżki pogańskiej, jak gdyby kontynuacji działalności wróżek z okresu wcześniejszego. W żywocie Brygidy nie widać jakiejś szczególnej ascezy, święta wydaje się bardzo pogodna... No i wreszcie w żywocie św. Patryka pióra Tirechana znajduje się ujmująca scena, w której dwie młode dziewczyny z królewskiego rodu przyszły do św. Patryka, żeby się dowiedzieć, co on głosi. Zacytuję fragment: „Powiedziała pierwsza córka: «Kim jest ów bóg, gdzie przebywa i czyim jest bogiem? Gdzie jest jego siedziba? Czy wasz bóg ma synów i córki, złoto i srebro? Czy jest zawsze żywy i piękny i czy jego syn posiada wielu wychowawców, a córki są drogie i piękne dla ludzi w świecie? W niebie przebywa, czy na ziemi, w morzu, w rzekach, w górach czy w dolinach? Opowiedz nam o nim, jak można go zobaczyć, wybrać i odnaleźć. Czy spotyka się go w młodości, czy na starość?»” Patryk wyłożył dziewczętom bardzo zwięźle prawdy wiary, po czym one poprosiły: „«Poucz nas najpilniej, w jaki sposób możemy uwierzyć Królowi niebieskiemu, abyśmy ujrzały Go twarzą w twarz. Powiedz nam, co mamy czynić, a postąpimy według twoich słów»". Zostały ochrzczone, powiedziano im jednak, że nie mogą „zobaczyć oblicza Chrystusa, zanim nie zaznacie śmierci i nie przyjmiecie Sakramentu”. „Przyjęły Eucharystię Bożą i pogrążyły się w śmiertelnym śnie”. 
Występuje dysproporcja pomiędzy praktyką często manifestowaną właśnie w utworach literackich, hagiograficznych a tą rzeczywiście, nawet jak na wczesne średniowiecze, wyjątkowo surową regułą Kolumbana. Reguły iryjskie nie miały szans, żeby być szerzej recypowane, bo raczej przekraczały możliwości grzesznego człowieka. Święty Benedykt wiedział, co robi...

P.Z. - Rzeczywiście, jego reguła zdobyła sobie wyjątkową popularność w Europie.

\section{J.S. - Dostosowana do natury ludzkiej...}

Jako uzupełnienie należy wspomnieć o niezwykle surowych praktykach ascetycznych wielu świętych iryjskich: tkwienie przez całe dnie i noce w lodowatej wodzie, samobiczowanie. Można powiedzieć, że te praktyki ascetyczne mnichów iryjskich przypominały często praktyki mnichów czy eremitów wschodnich. Ponadto opuszczanie wyspy: czasami udawano się, nie wiedząc, dokąd wiatry zawiodą. W sytuacji, kiedy człowiek stanowił cząstkę społeczności i poza społecznością żyć praktycznie nie mógł, to porzucanie rodzinnej wyspy, rodzinnego rodu i przenoszenie się, Bóg wie dokąd, oznaczało najwyższy możliwy stopień ascezy. Tam nie było wprawdzie pustyni, ale był ocean...

P.Z. - Święty Brendan, klasyczny przypadek... Czy można powiedzieć, że chrystianizacja barbarzyńców pociągała za sobą barbaryzację Kościoła?

J.S. - W jakimś stopniu tak, oczywiście, Kościół musiał przecież dostosować się do umysłów, do sposobów pojmowania... Trudno by mi było w tej chwili ten punkt rozwinąć, musiałbym zastanowić się nad tym, ale często, jeżeli chciano osiągnąć jakiś efekt, musiano dokonywać pewnych odstępstw od zasad wiary. Inaczej zapewne sytuacja wyglądała, jeżeli misjonarze sami pochodzili z tego ludu, który chrystianizowano, albo byli mu bliscy, a inaczej gdy przychodzili zupełnie z zewnątrz. Byli tacy, którzy nie mieli żadnego zrozumienia dla potrzeb pogan i działali bardzo bezwzględnie, ale ci zwykle odnosili mizerny skutek. Cała mądrość polegała na tym, żeby nie rezygnując z podstawowych zasad wiary chrześcijańskiej, które były oczywiście nie do przehandlowania, jednocześnie potrafić dostosować się... i to jest właśnie interesujące, że co bardziej światli papieże tej doby wiedzieli o tym doskonale. Mamy bardzo dobry przykład pouczenia misjonarzy, którzy działali w Anglii, gdzie wystawca listu, papież Grzegorz Wielki, wyraźnie mówi, żeby nie postępować zbyt gwałtownie, żeby ludzie nie odwracali się, żeby raczej próbować to, co możliwe, adaptować. Świątynie pogańskie niekoniecznie trzeba burzyć, wystarczy jeżeli się zniszczy idole pogańskie i dokona poświęcenia. Ludzie są przyzwyczajeni do zbierania się w tym miejscu, więc chętniej będą się tam 
gromadzili. Podobnie święta pogańskie: należy im nadawać chrześcijańską treść. Należy zachować miły zwyczaj urządzania uczt pogańskich, lecz nie na cześć bóstw, tylko dla oddania czci prawdziwemu Bogu i uprzyjemnienia tego momentu. Słusznie pod koniec dodaje, że przecież każdy wie, że gdy się chce wejść na wysoką górę, to przecież nie skokami czy biegiem, tylko powolnym krokiem, żeby ten cel osiągnąć. To była właściwa droga.

P.Z. - Kolejne pytanie odbiegnie nieco od historii misji w średniowieczu, ale też do tych dziejów nawiąże. Współczesne misje borykają się nieraz z problemem inkulturacji, dobrego przygotowania rodzimego kleru itp. Są takie ludy, które po dziesiątkach i setkach nawet lat ewangelizacji nie wydały rodzimego kapłana. Tymczasem w średniowieczu wystarczało kilka pokoleń, by Irlandczycy wydali wielkich ludzi Kościoła: Kolumbana, jednego, drugiego. Anglosasi Bedę Czcigodnego. Skąd ta różnica? Czy współcześni misjonarze gorzej głoszą Ewangelię od średniowiecznych, czy też była specyfika, która pozwalała tak szybko wydawać geniuszy myśli chrześcijańskiej owym ludom wczesnego średniowiecza?

J.S. - Ciekawy problem. Nie mam gotowej odpowiedzi na to pytanie. Wydaje mi się, że inna sytuacja jest tam, gdzie misje chrześcijańskie usiłują trafić do takich ludów, krajów, które mają już tradycyjnie pogłębione przekonania religijne. Chrześcijaństwo nigdy nie miało tam zbyt dużych sukcesów. Gdy, począwszy od XVI w., powstawały tam enklawy chrześcijańskie, działo się to pod znakiem kolonializmu, jak gdyby w konfrontacji z miejscowymi kultami i to często mści się w czasach późniejszych. Bardzo często w różnych miejscach kuli ziemskiej chrześcijaństwo jest traktowane jako pozostałość tego kolonialnego okresu. Bardzo często chrześcijaństwo było wprowadzane bez oglądania się na miejscowe tradycje i bez szanowania ich. Przecież w gruncie rzeczy dopiero w XIX w. rozpoczęły się nieśmiałe próby dążenia do inkulturacji. Wcześniej, w XVI czy XVII w., próby adaptacji chrześcijaństwa do miejscowych kultur (Indie, Chiny) posuwały się nawet zbyt daleko i te próby były tłumione przez Kościół (ostateczne potępienie rytów chińskich i malabarskich przez Benedykta XIV w XVIII w.). Poza tym, no cóż, bywa różnie, ale na przykład w Indiach i Chinach, czyli na terytoriach prastarych, wysoko rozwiniętych kultur, wpływy chrześcijaństwa miały i mają ograniczony zasięg. Nie wiem, czy tam i w przyszłości chrześcijaństwo ma jakieś szczególne szanse. Prawdopodobnie nigdy nie stanie się religią dominującą. Zresztą pytanie, czy należałoby do tego dążyć? Wiadomo, że po Soborze Watykańskim II Kościół inaczej zapatruje się na wartość duchową tych właśnie religii niechrześcijańskich. Także tu należałoby zaznaczyć, że Kościół odstąpił od doktryny, że nie ma zbawienia poza Kościołem, przynajmniej inaczej to obecnie się rozumie 
niż przed ostatnim soborem, ale to problem odrębny, wymagający szerszego spojrzenia.

P.Z. - Ten termin wrócił do swojego historycznego znaczenia, kiedy był wypowiedziany przez Cypriana z Kartaginy w konkretnym i precyzyjnym kontekście. Później rzeczywiście ewoluował w kierunku maksymy o bezkompromisowym i uniwersalnym zasięgu, a nie takie było jego pierwotne założenie, stąd faktycznie interpretuje się go w sposób pogłębiony.

J.S. - Ale proszę sobie wyobrazić takiego misjonarza wczesnośredniowiecznego czy nawet takiego, powiedzmy, w Kanadzie czy Paragwaju. Gdyby jemu powiedzieć, że poganie mogą również dostąpić zbawienia, byłby zgorszony, święcie przekonany, że to jest niemożliwe.

P.Z. - Był w tym element mocnej motywacji inspirującej gorliwość misyjną...

J.S. - „To po co w takim razie my się męczymy, narażamy się na niewygody, często na śmierć, jeżeli nie jest to konieczne z punktu widzenia możliwości zbawienia pogan" - mogliby zapytać misjonarze dawnych wieków...

P.Z. - Proszę pozwolić na pytanie nieco bardziej osobiste: jak zrodziła się fascynacja historią misji średniowiecznych bądź ludów, którym poświęcił Pan Profesor swe studia i badania naukowe?

J.S. - Moim zamierzeniem było nieco wzbogacić obraz dziejów Europy. Jeszcze przed kilkoma dziesięcioleciami, gdy studiowało się historię Europy średniowiecznej, to w praktyce była to historia Rzymu, a potem następował przeskok od razu do Europy karolińskiej i do dziedzictwa postkarolińskiego. Reszta była pomijana lub załatwiana ogólnikami. Nie wiem, czy zasadniczym, głównym, ale na pewno jednym z głównych celów moich naukowych dociekań było uzupełnianie tego obrazu o takie elementy, które były niedostrzegane. Chciałem i chcę pokazać, że dzieje Europy były bardziej bogate, zróżnicowane, niż by to wynikało z tradycyjnego schematycznego poglądu.

W tym celu najpierw zająłem się Słowianami Połabskimi. To są te ludy słowiańskie, które częściowo pogaństwo, ale i swój niezależny byt zachowały do XII w. i o których właściwie zapomniano. Nie pamięta się o nich ani w Niemczech, mimo że we wschodnich Niemczech na obszarze dawnej Niemieckiej Republiki Demokratycznej większość nazw miejscowych jest ciągle słowiańskiego pochodzenia. Także w Polsce właściwie zapomniano, że w średniowieczu byli jacyś Połabianie. Mimo że byliśmy sąsiadami, bo to wcale nie 
z Niemcami początkowo graniczyliśmy, tylko z tymi Słowianami Połabskimi. Zapomniano o nich, więc postarałem się w miarę możliwości, żeby ci Połabianie powrócili do łask, żeby ich dzieje, dole i niedole jakoś przedstawić. Potem przyszła kolej na germańskich Gotów, nieco później Wandalów jako ludy, które odgrywały kiedyś dużą rolę w dziejach Europy, naszego świata (epizodycznie nawet ziem polskich), a później zostały właściwie zapomniane. Do Wandalów żaden naród europejski nie ma ochoty się przyznawać. Notabene ciekawe, że przez moment chciano się w Polsce $\mathrm{z}$ nimi utożsamiać $\mathrm{w}$ średniowieczu, ale to był tylko epizod. Z Gotami owszem, z Gotami to i Szwedzi, i częściowo Hiszpanie się utożsamiali, ale to są zamknięte karty dziejów...

Iryjczyków, Iroszkotów uzasadniać nie trzeba. Była to karta bardzo słabo rozpoznana, zwłaszcza w nauce polskiej. Wreszcie niejako poza konkursem, ale w ostatnich latach zapragnąłem ten obraz wzbogacić o jeszcze jeden ważny element, mianowicie o miejsce i rolę kobiet w historii. Tak to już jest, że historię pisali mężczyźni, a zatem historia, jaką poznajemy, jest na ogół historią mężczyzn. Jednak przecież nic nie zmieni faktu, że połowę społeczeństwa stanowiły zawsze kobiety. Ponieważ miały w przeszłości bardzo ograniczone możliwości wypowiadania się, stąd ten świat kobiet poznajemy bardzo fragmentarycznie, najczęściej oczyma i z perspektywy mężczyzn. Nie zawsze obiektywnych. To jest taki projekt, który zajmuje mnie już od dłuższego czasu. Napisałem o tym dwa tomy, a zainteresowały mnie zwłaszcza te kobiety, które były mimo niesprzyjających warunków społecznych kreatywne pisarsko, które pisały coś, co się dochowało do naszych czasów. Od starożytnej Safony, po koniec średniowiecza; sądzę, że jest to bardzo mało znana karta z dziejów naszej cywilizacji.

Myślę, że w ten sposób wyjaśniłem, czym usiłuję się zajmować - tym co mniej znane. Najchętniej tym, co niedostatecznie zbadane, przynajmniej w polskiej nauce. Nie bardzo lubię poruszać się na gruncie, który był już omawiany i dyskutowany przez dziesiątki czy setki innych uczonych, np. znowu analizować kronikę Anonima Galla albo ten nieszczęsny dokument Dagome iudex. Lubiłem wkraczać na takie grunty, gdzie jest dużo do odkrycia, a także do udostępnienia polskiemu czytelnikowi, któremu też to się należy.

P.Z. - Czy studia nad misjami średniowiecznymi wymagają specjalnego przygotowania metodologicznego?

J.S. - Nie sądzę, żeby jakieś inne reguły metodologiczne były konieczne niż te, które obowiązują w postępowaniu historyka, zwłaszcza wcześniejszego średniowiecza. Musi pamiętać o tym, że z jednej strony powinien starać się w miarę możności wczuć się w ducha epoki, mentalność ówczesnych ludzi. Jest to podstawowy warunek, żeby nie modernizować, nie spoglądać na 
tych ludzi przez okulary człowieka XXI czy XX w., człowiek bowiem, mimo że natura ludzka jest podobno zawsze taka sama, jednak bardzo zmienia się w dłuższych okresach dziejowych. Inaczej postrzegano świat w czasach, gdy często brakowało racjonalnego naukowego wytłumaczenia, kiedy wszystko niemal można było thumaczyć jedynie magicznie lub odwołaniem się do woli Bożej. Wydaje się, że ten postulat jest powszechnie przyjęty. Z drugiej strony nie można bezkrytycznie ulegać optyce źródeł. Jak już wspomniałem, źródła iryjskie sugerują wysoki stopień religijności społeczeństwa. Jest to prawdopodobnie spowodowane tym, że większość tych źródeł powstała w środowiskach monastycznych i ma charakter bardziej postulatywny niż rzeczywisty, tak jak reguła Kolumbana odzwierciedla jakiś ideał, a nie żywe, istniejące społeczeństwo. Dotyczy to wszelkich możliwych dziedzin. Gdybyśmy na przykład chcieli zapytać z zupełnie innej dziedziny: jaka była narodowość ludzi mieszkających w miastach polskich w XIII czy XIV w., studiując źródła, a są to oczywiście przede wszystkim księgi miejskie, sądowe (jeżeli w ogóle się zachowały), trzeba by dojść do wniosku, że to byli prawie sami Niemcy. $\mathrm{W}$ tych księgach pojawiają się nazwiska i imiona, które przynajmniej początkowo jednoznacznie wskazują na pochodzenie niemieckie. Taki wniosek byłby niesłuszny. Dlaczego? Dlatego, że do tych ksiąg trafiali przede wszystkim przedstawiciele patrycjatu miejskiego, wśród których rzeczywiście Niemcy odgrywali główną rolę, podczas kiedy zwyczajny rzemieślnik czy kupiec, który mógł być Polakiem i na ogół na pewno był Polakiem, miał na to nikłe szanse. Chodzi o to, że historyk z jednej strony powinien wczuwać się w epokę, a to jest możliwe tylko dzięki źródłom, ale z drugiej strony nie może ulegać bezkrytycznie ich optyce. Ta optyka dotyczy całego wczesnego średniowiecza. Ogromna większość źródeł średniowiecznych jest proweniencji kościelnej, a przede wszystkim monastycznej, zatem odzwierciedlają przede wszystkim tę stronę życia. Inny przykład, gdybyśmy zadali pytanie, jaka była własność ziemi w Polsce wczesnego średniowiecza, powiedzmy do XIII w., to wertując nieliczne źródła, a tymi źródłami byłyby przede wszystkim dokumenty praktyki prawnej, trzeba by dojść do wniosku, że niemal cała ziemia była w rękach Kościoła. To oczywiście byłoby wnioskiem tylko formalnie poprawnym. Tak wynika ze źródeł. Ale dlaczego? Dlatego, że zachowały się czy były wówczas wytwarzane niemal wyłącznie źródła proweniencji kościelnej. One nas informują o dobrach będących w rękach Kościoła albo o przechodzących w jego ręce. Tymczasem wiemy, że we wczesnym średniowieczu w posiadaniu klasztorów, biskupów, kapituł znajdowało się może kilka procent ziemi uprawnej w Polsce. Trochę więcej było w ręku króla czy panującego księcia, ogromna większość pozostawała natomiast w rękach rycerzy czy wolnych chłopów, ale ta własność nie miała żadnych szans zaistnieć w źródłach, jedynie, jak mówiłem, w przypadku przekazywania na własność Kościoła. Kościół dbał o to, 
żeby to zachować na piśmie, bo w rodach rycerskich pamięć trwała, a w instytucjach kościelnych tej ciągłości nie było. Dlatego dobrze było mieć dokument na piśmie i stąd ta nasza zwichnięta perspektywa. Nie możemy tu zawierzyć źródłom, to byłoby niehistoryczne podejście. Także wyszliśmy tu od...

P.Z. - Pytania o specjalną metodologię studiowania misji średniowiecznej. Po prostu jest to metodologia typowa dla badacza średniowiecza...

J.S. - Musi korzystać często z metody porównawczej. Polega ona na tym, że wnioskujemy o jakieś rzeczy, np. o pogaństwie polskim, o którym właściwie nic nie wiemy, na podstawie lepiej znanych stosunków połabskich, pomorskich czy ruskich. Pod warunkiem oczywiście, że porównujemy rzeczy porównywalne, bo tylko takie można sensownie porównywać. Często wykorzystujemy tę metodę, podobnie jak metodę retrospektywną, polegającą na tym, że z późniejszych stosunków (z reguły lepiej znanych) wnioskujemy o mniej znanych wcześniejszych. Metody te są dobrze znane w nauce historycznej. Trzeba je stosować, ale to są metody pośrednie i wymagają dużej ostrożności badawczej.

P.Z. - Wspomniał Pan Profesor o pasji zajmowania się tematami mniej znanymi. Jeśli chodzi o misje w Europie wczesnośredniowiecznej, to już w Pana książkach traktujących o Gotach czy o Wandalach pojawiają się wątki związane z dziejami chrystianizacji Europy. Później doszła książka Apostołowie Europy, w której Pan przybliża postacie najwybitniejszych misjonarzy średniowiecznych. Jak z perspektywy własnego zaangażowania w upublicznianie tych właśnie tematów historycznych ocenia Pan Profesor stan polskiej historiografii dotyczącej misji średniowiecznych?

J.S. - Wprawdzie zmienia się na lepsze, ale stopień rozpoznania w nauce polskiej tego zjawiska jest na pewno niewystarczający. Banalne stwierdzenie, bo który historyk powie, że wystarczająco dużo o czymś już wiemy. Są pewne dziedziny, pewne fragmenty lepiej rozpoznane dzięki historykom Kościoła czy patrologom, którzy sporo uczynili i nadal czynią. Trudno się dziwić, jest to dla nich problem na pewno bardziej istotny niż dla większości świeckich historyków, ale sytuacja powoli zmienia się na lepsze. Po pierwsze, idzie to w parze z ogólnym niesłychanym rozwojem nauki historycznej. Chyba nigdy w dziejach naszej cywilizacji nie było tylu historyków jak w ciągu ostatnich kilkudziesięciu lat. To jest funkcja tego dynamicznego wzrostu, choć nie zawsze ilość przechodzi w jakość. Historycy zajmują się również różnymi zjawiskami zbliżonymi do misji czy chrystianizacji. W różnych ośrodkach Polski są uczeni w bardziej systematyczny sposób podejmujący badania nad tymi sprawami. 
Ośrodek warszawski, zwłaszcza młodsi uczeni skupieni obecnie pod okiem Profesora Romana Michałowskiego, sporo czynią dla rozpoznania epoki ottońskiej, także w tym misyjnym aspekcie. Ośrodek krakowski wyspecjalizował się, tj. wydał kilku specjalistów, jeżeli chodzi o wyprawy krzyżowe i zagadnienia z tym związane. Zresztą wyprawy krzyżowe to jest problem, którym zajmują się uczeni w różnych ośrodkach Polski, np. w Toruniu, Lublinie, we Wrocławiu, także w Poznaniu. Jednym z postulatów badań nad misjami jest udostępnianie podstawowych tekstów związanych z historią misji, zarówno jeżeli chodzi o teorie misyjne, o wypowiedzi Kościoła czy jego przedstawicieli na temat misji, jak również dotyczących samej praktyki misyjnej. Wydaje mi się, że byłaby dość pilna potrzeba zaprezentowania odpowiedzialnej naukowo, dość obszernej antologii tekstów misyjnych w polskim przekładzie. Mało tknięte w polskiej nauce są misje Kościoła wschodniego, czyli bizantyjskiego, a także ruskiego oraz tych misji dalekowschodnich, o których poprzednio wspomniałem. Te sprawy właściwie mało były dotąd badane, rozpatrywane i dostrzegane w polskiej nauce historycznej. No, ale nie można się jednocześnie wszystkim zajmować.

P.Z. - Tu właściwie Pan Profesor odpowiedział na kolejne moje pytanie, które miało dotyczyć ewentualnych postulatów, jeżeli chodzi o publikacje źródeł misyjnych. Usłyszeliśmy, że dobrze widziana byłaby taka poważna antologia. Przejdę zatem do ostatnich pytań, może znów nieco bardziej szczegółowych. Czy myśląc o średniowiecznych misjonarzach - ,apostołach” Europy, trzeba ich podziwiać, czy też patrzeć krytycznie, jak na intruzów w świecie obcych sobie kultur? Nieraz w krytycznych ocenach historii wczesnego średniowiecza pojawia się zarzut pod adresem Kościoła, że był intruzem w dobrze funkcjonujących miejscowych społecznościach. Czy historyk może podziwiać, czy raczej zmuszony jest patrzeć krytycznie na tych wybitnych misjonarzy, których choćby Pan Profesor opisał w książce Apostołowie Europy?

J.S. - Na upartego można by na fragmenty działalności niektórych z tych misjonarzy spoglądać krytycznie. Zwłaszcza jeżeli się zapomni o tym postulacie, że na epokę należy spoglądać w taki sposób, jak czynili to ówcześni ludzie, a nie $\mathrm{z}$ wyżyn postoświeceniowego, zlaicyzowanego $\mathrm{w}$ dużym stopniu świata. Osobiście nie zetknąłem się z poglądem, który by potępiał wysiłki misjonarzy, także tych wczesnośredniowiecznych. Owszem, w polskiej nauce bardzo krytycznie zawsze się wypowiadano o działalności misyjnej zakonu krzyżackiego na terenie Prus i Litwy. Nie przecząc, że istniały negatywne strony tej działalności, uważam, że w polskiej nauce historycznej zbyt jednostronnie zapatrujemy się na rolę zakonu Najświętszej Maryi Panny Domu Jerozolimskiego. To prawdziwie antykrzyżacka histeria, jaka panuje w Polsce od drugiej poło- 
wy XIX w., chociaż rzeczywiście wcześniej były zatargi, wojny itd. Jednak Krzyżacy pewne zasługi w dziele chrystianizacji mieli. To nie jest tak, że oni wytępili Prusów, przeciwnie, Prusowie pod ich rządami istnieli dość długo, do póki nie wytworzyło się ,nowe plemię niemieckie” Prusów, ale to tak na marginesie, nie warto nad tym specjalnie się rozwodzić...

To było wielkie dzieło. Uważam, że proces chrystianizacji Europy jest jednym z głównych wątków dziejów naszej cywilizacji. Czasami można zamknąć oczy i pomyśleć, co by było, gdyby to nie nastąiło, gdyby Europa nie stała się chrześcijańska. Tu wyobraźnia zawodzi, ale nie sądzę, żeby dzieje Europy bez chrześcijaństwa były szczęśliwsze, bardziej harmonijne. Czy później islam mógłby wypełnić tę lukę, trudno powiedzieć, to byłaby historia kontrfaktyczna. Uważam, że chrystianizacja przyniosła pozytywne, już nie chcę używać tego słowa - błogosławione skutki, zwłaszcza spoglądając z punktu widzenia globalnego. Wiadomo, że dzięki chrześcijaństwu do Europy mogła zostać przeniesiona i rozwijana w niej kultura grecka i rzymska. Chociaż były w obrębie Kościoła nurty bardziej redukcjonistyczne, nieufne, skłonne raczej ograniczyć wpływy kultury antycznej. Także z punktu widzenia, powiedzmy, organizacji społecznej, państwowej chrześcijaństwo przyczyniło się do konsolidacji europejskich ustrojów państwowych i do wyjścia z kosmosu pierwotnego, którego nie mamy powodu idealizować. To była wojna wszystkich ze wszystkimi. Państwo razem z chrześcijaństwem wprowadzało porządek i pewien ład. No i wreszcie, z indywidualnego punktu widzenia: chrześcijaństwo w dużym stopniu zaspokoiło pewną potrzebę duchową człowieka, jeżeli prawdą jest, że jakaś część osobowości ludzkiej tęskni za czymś, co pozaziemskie, albo oczekuje sprawiedliwości. Tu, na Ziemi, wprawdzie jest wiele niesprawiedliwości, ale to ma zostać kiedyś wyrównane. Krzywdziciele zostaną ukarani, a ci, którzy żyją godnie, ubodzy, prześladowani, będą mogli łatwiej wejść do królestwa niebieskiego. Będzie to dla nich niewątpliwie jakaś rekompensata. Chrześcijaństwo nie zapobiegło wprawdzie wojnom religijnym, gwałtom czy inkwizycji, ale - na ogół rzecz biorąc - zmniejszało niesprawiedliwość społeczną. Można było tego chłopa czy niewolnika gnębić, ale u większości ludzi tkwiło przekonanie, że kiedyś trzeba będzie z tego zdać rachunek. To zapewne mogło wpływać i wpływało na pewne zelżenie tej niesprawiedliwości, tego gwałtu.

Wspomnę też o takich sprawach, jak dowartościowanie, przynajmniej w sferze prawnej, społecznej roli kobiet, która w okresie pogańskim w Rzymie czy też w Grecji była znacznie niższa. Mam na myśli przede wszystkim małżeństwo chrześcijańskie, które z założenia teoretycznie, a później także praktycznie było małżeństwem monogamicznym. Natomiast, moim zdaniem, zjawiskiem niekorzystnym dla sytuacji kobiet było wypieranie ich z instytucjonalnego Kościoła. Począwszy od czasów postapostolskich aż po nasze 
czasy rola kobiet została bardzo ściśle ograniczona, wręcz zminimalizowana w przeciwieństwie do czasów pogańskich, kiedy to w sferze religijnej kobietom przypisywano większą rolę, ale to już jest znowu osobny problem.

Wiadomo, że immanentną cechą chrześcijaństwa była działalność misyjna. Żadna $\mathrm{z}$ innych religii światowych takiego zadania, celu misyjnego jak chrześcijaństwo nie miała ani religia mozaistyczna, która mimo pewnych prób wyjścia zasadniczo była i pozostała religią narodu wybranego, ani islam, mimo wielkich sukcesów na początku średniowiecza, a także w dzisiejszych czasach. Celem muzułmanów nie było nawracanie na islam, kto chce, owszem, może go przyjąć, ale celem islamu w średniowieczu był podbój świata. Tym bardziej wielkie religie Wschodu jak hinduizm, buddyzm, konfucjanizm nigdy, aż właściwie do naszych czasów, nie stawiały sobie za cel działalności misyjnej. To były religie dla własnych społeczności mimo dużych sukcesów, zwłaszcza hinduizmu i buddyzmu w naszych czasach, na różnych kontynentach. No, ale to znowu zupełnie odrębna sprawa. Natomiast misje, dążenie do nawracania stanowiło cechę wyróżniającą chrześcijaństwo. Docete omnes gentes...

P.Z. - Teraz zadam pytanie bardzo ogólne: którego z „,apostołów” Europy uznałby Pan Profesor za najwybitniejszego misjonarza?

J.S. - Odpowiedź jest o tyle trudna, że ich dokonania bardzo się różniły między sobą. Najbardziej wbili się w świadomość Europejczyków chyba św.: Winfryd-Bonifacy, Konstantyn i Metody oraz Wojciech. Wszystkie te trzy przypadki są nietypowe.

Główne zasługi Bonifacego polegają nie na nawracaniu na chrześcijaństwo, tylko na organizowaniu życia kościelnego na terenie Germanii. Stosunkowo nieczęsto występował w charakterze rzeczywistego misjonarza, a gdy raz wystąpił we Fryzji, to szybko poniósł śmierć męczeńską.

Konstantyn i Metody, uznani obok św. Benedykta za patronów Europy przez Stolicę Apostolską, w zasadzie nie prowadzili działalności misyjnej, działali bowiem wśród Morawian, a następnie wśród Słowian Panońskich na obszarach, które już wcześniej były schrystianizowane. Główne zasługi Konstantyna, a zwłaszcza Metodego, bo Konstantyn wcześniej umarł, polegały, po pierwsze, na stworzeniu organizacji kościelnej, która zresztą i tak okazała się nietrwała. Wiekopomna ich zasługa to położenie podstaw pod kulturę i piśmienność Słowiańszczyzny przez stworzenie alfabetu słowiańskiego.

Wreszcie Wojciech. Na dobrą sprawę nie wiemy, czy w ogóle kogokolwiek ochrzcił. Powiem rzecz troszkę niepopularną w Polsce - przecież to był w gruncie rzecz jeden wielki nieudacznik, czego się tknął, to właściwie zawalił. $\mathrm{Z}$ własnej diecezji wygonili go diecezjanie, bowiem stawiał jakieś wy- 
magania, których oni nie podzielali. Udał się do Prusów, bo musiał. Jeżeli nie mógł wrócić do swojej diecezji, to alternatywą było podjęcie misji wśród pogan. Zapewne to z inicjatywy dworu polskiego, Bolesława Chrobrego, udał się do Prusów. Wbrew wszelkim późniejszym legendom zarówno na terenie Węgier, jak i na terenie Polski, niewiele zdziałał. Ledwo znalazł się na terytorium Polski, to zginął śmiercią męczeńską. A zatem w formalnym sensie niewiele osiągnął, a jednak jest wielkim świętym, wielkim patronem. Także dlatego, że w tym okresie, kiedy to na ogół misje prowadzono ogniem i mieczem albo w sposób zbliżony, on zaprezentował typ odmienny, ewangeliczny. Do Prusów udał się bez zbrojnej eskorty, którą mu Bolesław proponował. Znacznie bardziej efektywny od Wojciecha był jego następca, Brunon z Kwerfurtu, który rzeczywiście był misjonarzem w pełnym tego słowa znaczeniu wśród różnych ludów Europy. Zawędrował aż do Pieczyngów. Rzeczywiście osiągnął duże efekty. Jednak kto w Polsce o nim pamięta? Uległ zupełnemu zapomnieniu. Nawet w Niemczech nie bardzo o nim pamiętano, dopiero ostatnio zaczęto się nim ponownie interesować. Pamięć historyczna bywa niesprawiedliwa, bywa też selektywna. Jak widać, żaden z tych największych nie był misjonarzem we właściwym tego słowa znaczeniu. A kto pamięta w tej chwili o Wilibrordzie czy o Ottonie z Bambergu? O Ottonie z Bambergu, ,,apostole Pomorzan”, też zupełnie w Polsce przez wieki nie pamiętano. Dopiero w XIX w. ponownie wróciła o nim pamięć.

P.Z. - Kilku z tych wymienionych misjonarzy zakończyło życie śmiercią męczeńską. Wydaje mi się, że istnieje rodzaj ciągłości między ideałem chrześcijanina-męczennika starożytności, następnie (po ustaniu prześladowań) chrześcijanina-mnicha, który idzie na pustynię i prowadzi tam surową ascezę, i wreszcie misjonarza, który znowu świadomie podejmuje pewne ryzyko podczas konfrontacji z obcą kulturą oraz obcym państwowym systemem i sam naraża się na męczeństwo, często wręcz go pragnie. Czy - zdaniem Pana Profesora - w przypadku tych średniowiecznych misjonarzy męczeństwo nie wynikało nieraz z pewnej świadomej prowokacji?

J.S. - Tak, na pewno. Często świadomie prowokowali. Z naszego punktu widzenia to było niesłuszne, ale często tak samo oceniano to z ówczesnego punktu widzenia, bo gdyby inaczej postępowali, mniej prowokacyjnie, mogliby osiągnąć więcej. Mówi się, że krew misjonarzy zawsze ma religijne uzasadnienie. Historyk może na to spoglądać tylko z ziemskiego punktu widzenia. Jednak rozumiemy, że prowokacja była czasem niezbędna. Na ogół bardziej do pogan przemawiały czyny niż słowa. Ze słów jeszcze niewiele rozumieli, niewiele chcieli zrozumieć i niewiele potrafili rozumieć. Często się mówi, że taka misja wśród ludów pogańskich, pierwotnych, to była misja czynu, a nie 
słowa. Słowo mogło przyjść później. Najpierw trzeba było udowodnić, że Bóg chrześcijan jest potężny, a tamte bóstwa to są idole, bezsensowne dzieło rąk ludzkich. Żeby to udowodnić, dobrze było czasami ściąć ten święty dąb albo obalić posąg po to, żeby poganie zobaczyli, że został obalony i nic się nie dzieje. Bóstwo nie interweniuje, a zatem jest bezsilne.

Bardzo często tym czynem było sprawianie cudów. Nic tak bardzo nie przemawiało do ówczesnych ludzi jak to, że misjonarze potrafili czynić rzeczy nadnaturalne. Dlatego opisy misji pełne są cudów. Historyk musi zamilknąć, nie jest w stanie powiedzieć, czy tak było naprawdę, czy nie. Raczej pozostanie sceptykiem. Jeżeli się dowie z jakiegoś żywota, że święty wlazł do ognia po to, żeby pokazać, że Bóg chrześcijański jest silniejszy, podczas kiedy kapłan pogański po wejściu w ogień od razu spłonął czy się poparzył, to musi zamilknąć, nie może się na ten temat wypowiedzieć, ale to działało. Prawdziwe albo domniemane cuda były skuteczne.

Poza tym może na nieco późniejszym etapie dochodziły takie namacalne argumenty, jak budowanie kościołów. Wiadomo, że budowano drewniane, ale tam, gdzie to było możliwe, także kamienne. Nikłe początkowo wspólnoty misyjne, zakonne, klasztorne przynosiły ze sobą pewne wzorce gospodarowania. Misjonarze przybywali na ogół z bardziej rozwiniętych krajów. No więc ci niedawni poganie widzieli, że ta nowa religia w jakiś sposób wiąże się z osiągnięciami cywilizacyjnymi. Gdy chrześcijanie zwyciężali na polu bitewnym, wtedy to był już dowód namacalny, że Bóg chrześcijan jest potężniejszy od bóstw rodzimych.

Jednak były też przeszkody. Można bowiem zapytać: skoro tak, to dlaczego proces chrystianizacji trwał tak długo. Dlaczego ginęli misjonarze, dlaczego zdarzały się apostazje i powroty do pogaństwa? Przecież dzieje misjonarzy to często pasma klęsk. Może warto przytoczyć przykład fryzyjskiego króla Radboda. To jest pierwsza połowa wieku VIII, mamy taki ciekawy opis w jednym z żywotów biskupa, który tam działał. Biskup kiedyś niemalże już rzekomo przekonał tego Radboda, że warto stać się chrześcijaninem. Już miała się dokonać ceremonia chrztu, wtedy to się dokonywało przez wejście do chrzcielnicy, no i ten Radbod już jedną nogą w niej był, ale coś go tchnęło i pyta: „Panie Biskupie, ale co będzie po śmierci, czy tam spotkam się z moimi szlachetnymi przodkami, książętami, królami?” Biskup musiał go wyprowadzić z błędu: „To jest niemożliwe szlachetny książę, ponieważ to byli poganie i oczywiście będą gdzie indziej”. Na takie dictum Radbod wyjął stopę z chrzcielnicy i powiedział: „To ja dziękuję, ja wolę zamiast z tymi biedakami chrześcijańskimi $\mathrm{w}$ niebie być gdzie indziej z moimi szlachetnymi przodkami”. Bo co to za alternatywa! Książęta, którzy rozumowali w arystokratycznym duchu, mieli być na jednym poziomie z wyznawcami religii, która ciągle miała posmak plebejski, uchodziła za religię niewolników, sług i poddanych. 
Radbod jest przykładem arystokratycznych oporów mentalnych przeciwko chrześcijaństwu.

P.Z. - Mój niemiecki współbrat-historyk wyczytał w średniowiecznych źródłach następujący przykład: misjonarz chrzcił kolejne grupy germańskich pogan; pewnego dnia nowo ochrzczeni wydali mu się wyjątkowo smutni; zapytani o przyczynę smutku rzekomo odpowiedzieli: „Kiedy poprzedni raz byliśmy ochrzczeni, dostaliśmy lepsze podarki..." To kolejny przykład specyficznego patrzenia na kwestię nawrócenia w średniowieczu.

J.S. - Któreś polskie źródło też donosi, że jak Polacy z polecenia króla Jagiełły chrzcili Litwinów, to niejeden z nich przychodził kilka razy, bo za każdym razem dostawali jakiś podarunek. Nasuwa mi się jeszcze refleksja, choć to wykracza poza kwestie, o których rozmawiamy, jak traktować misje prowadzone przez nieortodoksyjnych chrześcijan (tzw. heretyków) albo przez wyznawców innych religii, np. misje żydowskie, muzułmańskie, misje donatystów, arian, nestorian czy monofizytów. Gdyby również tymi mało rozpoznanymi i najczęściej pomijanymi w opracowaniach misjami chciały się „Annales” zająć, byłoby to duże wyzwanie i otwarcie nowych horyzontów poznawczych.

P.Z. - Opublikowaliśmy kilka lat temu w tomie pokonferencyjnym artykuł francuskiego historyka misji, który omawiał chrystianizację Nubii. Wystąpił tam ciekawy proces ścierania się misji chalcedońskich z monofizyckimi. Wszystkie były inspirowane przez dwór cesarski w Konstantynopolu, gdyż Teodora, żona Justyniana, sympatyzowała z monofizytami...

J.S. - Byłoby rzeczą pocieszającą, gdyby również w naszym kraju uczeni zechcieli bardziej się tym wszystkim zajmować. Jest problem teologiczny, czy można mówić o męczennikach za wiarę poza Kościołem. Panowało przekonanie, że nie wystarczy śmierć męczeńska, ale jeszcze musi być w słusznej, czyli katolickiej sprawie.

P.Z. - Na Soborze Florenckim w akcie unii z Koptami zadeklarowano: „kto nie pozostaje w łonie Kościoła katolickiego w jedności i zgodzie, nie osiągnie zbawienia, nawet gdyby spełniał wszelkie dobre uczynki, nawet gdyby przelał krew i umarł dla imienia Chrystusa - nic mu nie pomoże"2. Oczywiście należy ten tekst interpretować w należnym mu kontekście. Paweł VI w dniu kanonizacji męczenników z Ugandy wspomniał także z życzliwością o męczennikach anglikańskich...

\footnotetext{
${ }^{2}$ Por. Dokumenty Soborów Powszechnych, t. 3 (1414-1445), red. A. Baron, H. Pietras, Wydawnictwo WAM, Kraków 2004, s. 605.
} 
J.S. - Długo trwało, nim do tego doszło, ale w końcu... Podobnie było z kwestią zbawienia nieochrzczonych dzieci.

P.Z. - Są to przykłady niewątpliwego rozwoju wrażliwości teologicznej. Natomiast chciałbym jeszcze zapytać, jakie sugestie miałby Pan Profesor dla studentów zainteresowanych tematem misji średniowiecznych, gdyby związali z nim swoją pasję naukową, badawczą. Od czego powinni zacząć?

J.S. - Od wybrania jakiegoś specjalnego zagadnienia, bo nie można się wszystkim zajmować. W zależności od tego wyboru trzeba by odpowiednio pokierować swoim wykształceniem. Niestety, nie jest to łatwa sprawa, także ze względu na kwestię językową, która jest barierą. Jeżeli ktoś chciałby się zajmować misjami wśród ludów germańskich, to sprawa jest jasna, bez znajomości języka źródeł trudno o wyniki, tym bardziej że, jak wspomnieliśmy, polska oferta, jeżeli chodzi o dostępność źródeł, jest nader ograniczona. Z niektórych dziedzin w ogóle nie ma źródeł tłumaczonych na język polski, ale gdyby kogoś to interesowało, a myślę, że warto byłoby się tym zainteresować, to ciągle jest sporo do odkrycia. Może jeszcze nie na etapie licencjackim, ale magisterskim, takimi ludźmi trzeba pokierować i zachęcać do tego. Ja, niestety, jako spokojny emeryt jestem już poza tym...

P.Z. - Zatem kluczową sprawą jest studiowanie języka źródeł oraz pasja, żeby się z nimi zmagać.

J.S. - Język źródeł i poza tym literatura, też jest wielojęzyczna, to stanowi pewną przeszkodę, ale nie jest tak najgorzej. Tu i ówdzie w Polsce widać już, nawet wśród świeckich uczonych, że pojawiają się zainteresowania tą ważną i pasjonującą problematyką.

P.Z. - Bardzo serdecznie dziękuję za rozmowę!

\author{
AN INTERVIEW ON THE HISTORY \\ OF CHISTIAN MISSION IN THE MIDDLE AGES
}

\title{
SUMMARY
}

On September 25-26th 2014 the Institute of History, Adam Mickiewicz University in Poznań, has organized a conference „Christianization of Europe. The Church at the turn of the first and second millenium". It was the first of planned three confer- 
ences which preceed the 1050 anniversary of the baptism received by Polish prince Mieszko I in 966 and the official introduction of Christianity to Poland. Prof. Strzelczyk was one of the main organizers of this conference and the discussion reported below touches the subjects related to his professional career as a historian, focusing on the study of the history of Christian missions in Middle Ages.

Keywords: medieval missions, methodology of history, Celtic and Slavonic culture, Hiberno-Scottish mission

Słowa kluczowe: misje średniowieczne, metodologia historii, kultura Celtów, kultura Słowian, misja iroszkocka

Profesor DR HAB. JeRZY STRZELCZYK - emerytowany profesor w Instytucie Historii Uniwersytetu im. Adama Mickiewicza w Poznaniu, mediewista, specjalizujący się w średniowiecznych dziejach Polski i Europy, zwłaszcza politycznej, społecznej, etnicznej i intelektualnej historii wczesnego i pełnego średniowiecza, historii Słowian i stosunków słowiańsko-germańskich (polsko-niemieckich), wiedzy i wyobraźni geograficzno-etnograficznej średniowiecza (wraz z historią odkryć geograficznych), misji chrześcijańskich, miejsca kobiet w historii kultury europejskiej i pozaeuropejskiej. Był m.in. kierownikiem Zakładu Historii Średniowiecznej, prodziekanem Wydziału Historycznego, prorektorem Uniwersytetu im. Adama Mickiewicza w Poznaniu i dyrektorem Instytutu Historii Uniwersytetu im. Adama Mickiewicza w Poznaniu. Członek-korespondent PAN, członek czynny PAU, doktor honoris causa Akademii Pedagogicznej im. Jana Długosza w Częstochowie i Uniwersytetu Wrocławskiego. Autor wielu prac, z których ostatnia to: Longobardowie. Ostatni z wielkiej wędrówki ludów V-VIII w., PWN, Warszawa 2014. 
